\title{
Heterogeneity of B Lymphocyte Differentiation in Severe Combined Immunodeficiency Disease
}

\author{
Savita G. Pahwa, Rajendra N. Pahwa, and Robert A. Good, \\ Department of Immunobiology, Memorial Sloan-Kettering Cancer Center, \\ New York 10021
}

A B S T R A C T Pokeweed mitogen-induced B lymphocyte differentiation in vitro into antibody secreting plaque-forming cells (PFC) was investigated in nine patients with severe combined immunodeficiency having variable proportions of circulating B lymphocytes. When cultured by themselves, the peripheral blood mononuclear cells did not respond to stimulation with pokeweed mitogen in any patient. In the presence of irradiated allogeneic $\mathrm{T}$ cells as helpers, however, PFC responses were elicited in lymphocyte cultures from peripheral blood and/or bone marrow in some patients. In one of these patients, results of allogeneic co-culture experiments were suggestive of genetically restricted suppressor cells. In a single patient with deficiency of the enzyme adenosine deaminase, PFC were generated in bone marrow lymphocyte cultures only when they were supplemented with exogenous adenosine deaminase and allogeneic helper cells.

A parallel study of $\mathrm{T}$ lymphocyte differentiation in vitro performed in fractionated bone marrow cells was suggestive of arrested differentiation at different steps along the differentiation pathway. In two patients with evidence of functional B cell precursors, deficiencies of helper $\mathrm{T}$ cell function could be attributed to differentiation defects at the level of the stem cells in one and the thymus in the other. The findings reported here further substantiate the heterogeneity of the severe combined immunodeficiency disease syndromes.

\section{INTRODUCTION}

The syndrome of severe combined immunodeficiency disease (SCID) ${ }^{1}$ represents a group of congenital lethal

This work was presented in part at the annual meeting of the Society for Pediatric Research in Atlanta, Ga., 1979.

Received for publication 11 December 1979 and in revised form 31 March 1980.

${ }^{1}$ Abbreviations used in this paper: ADA, adenosine deaminase; HTLA, human T lymphocyte antigen; PBM, peripheral blood mononuclear cells; PFC, plaque-forming cells; PWM, pokeweed mitogen; SCID, severe combined immuno- disorders, characterized by defects of both $B$ and $T$ cell systems (1). Proportions of T lymphocytes in peripheral blood are markedly reduced, but numbers of B lymphocytes are very heterogenous, ranging from complete absence to increased proportions, and even increased absolute numbers. Although $B$ and $T$ lymphocyte function in these patients is grossly deficient in vivo, B cells from some patients have been shown to undergo terminal differentiation in vitro in the presence of pokeweed mitogen (PWM) and normal T cells $(2,3)$. Antigen-specific antibody producing plaque-forming cells have been shown to be generated in peripheral blood mononuclear cells of one patient with SCID after their incubation with thymic epithelial monolayers (4). This capacity may have reflected induction of helper cell function in the patient's own cells due to exposure of thymic influences. The above observations suggest that in some patients with SCID, circulating B cells may be intrinsically normal, but fail to function in vivo.

In this study, we have examined B and T lymphocyte differentiation responses in peripheral blood as well as in the bone marrow of SCID patients, and have investigated the relationship of $B$ cell differentiation defects with abnormalities of $T$ lymphocyte differentiation in vitro. Our observations suggest that the majority of patients with SCID have abnormalities of both $B$ and $T$ cell lineages. In the group of patients with intrinsically "normal" B cells in their circulation, failure of $B$ cell function may be attributed not only to deficiencies of helper $T$ cells but also to an excess of suppressor cells.

\section{METHODS}

Patients. The patients studied were 6 mo to $2 \mathrm{yr}$ of age at the time of study. Pertinent laboratory information has been previously reported (5) and is shown in part in Table I. The patients were lymphopenic $(<1,500$ counts $/ \mathrm{mm})$ and their lymphocytes failed to proliferate in response to mitogens,

deficiency disease; TEM, thymic epithelial monolayers; Tx, irradiated normal $\mathrm{T}$ cells. 
antigens or allogeneic cells in the conventional tests. Proportions of $B$ lymphocytes were markedly increased in three patients (B, H, and $\mathrm{J})$. T lymphocytes were decreased in all patients except one (K), who had $\mathrm{T}$ cells of maternal origin (determined by sex karyotype) in the circulation. Clinical information on these patients has been recently reported (6).

Studies described here were performed before any treatment aimed at immunologic reconstitution in all patients except two ( $B$ and F). The latter two patients had been given fetal liver transplantation and exhibited donor cell chimerism in peripheral blood, but were without immunologic reconstitution at the time of the present study.

Isolation of cells. Peripheral blood mononuclear cells (PBM) from patients were obtained by centrifugation of $\sim 10$ ml of diluted, heparinized venous blood on sodium metrizoate/ Ficoll cushions (Lymphoprep, Nyegaard and Co., Oslo). Control blood, obtained from healthy laboratory personnel 20-45 yr of age, was separated in a similar manner. For the bone marrow studies, small volumes $(0.5-0.7 \mathrm{ml})$ of marrow were aspirated from several sites on the iliac crest into heparinized glass syringes. Mononuclear cells were first isolated by floatation on metrizoate/Ficoll cushions and then further fractionated by velocity sedimentation at unit gravity (7). Cells from different fractions were pooled to yield the following cell populations: pool 1 (fractions 1-10), consisting largely of cells of the myeloid series; pool 2a (fractions 11-13), consisting mainly of monocytes and a few large lymphocytes; pool $2 b$ (fractions $14-16$ ), containing predominantly medium sized lymphocytes; and pool 3 (fractions 17-24), containing mainly small lymphocytes.

T lymphocytes were isolated from normal PBM by rosette formation with neuraminidase-treated sheep erythrocytes (8) and subsequent centrifugation on standard sodium metrizoate/ Ficoll gradients.

Assay for B lymphocyte differentiation. $\mathrm{PBM}$ were stimulated in vitro with PWM and subsequently tested for secretion of antibody to sheep erythrocytes in a plaque assay. Culture conditions and assay system were adapted (9) from those described by Fauci and Pratt (10). Briefly, $10^{6}$ cells in medium RPMI with penicillin $50 \mathrm{U} / \mathrm{ml}$, streptomycin $50 \mu \mathrm{g} / \mathrm{ml}$, glutamine $2 \mathrm{mM}$, trypticase soy broth $1 \%$, and human $\mathrm{AB}$ serum $10 \%$ (previously absorbed with sheep erythrocytes) were cultured in $12 \times 50$-mm plastic tubes in the presence or absence of PWM (final dilution ranging from 1:20 to 1:1,000).

Culture tubes were rocked at $7 \mathrm{cycle} / \mathrm{min}$ on a rocker platform at $37^{\circ} \mathrm{C}$ in $5 \% \mathrm{CO}_{2}, 95 \%$ air and $100 \%$ humidity for $6 \mathrm{~d}$. Upon termination of cultures, cells were washed twice in medium RPMI and plated in $0.5 \%$ noble agar with sheep erythrocytes and guinea pig complement in a modified Jerne plaque assay. After incubation at $37^{\circ} \mathrm{C}$ with humidification for $3 \mathrm{~h}$, plaques were counted against indirect light. Results are expressed as plaques per million cells plated.

In some experiments, normal $\mathrm{T}$ cells irradiated to 1,500 $\operatorname{rad}(\mathrm{Tx})$ were used as helper cells, and added to test cells in a 1:1 ratio at initiation of culture, keeping the final volume and cell concentration constant at $1 \times 10^{8} \mathrm{cells} / \mathrm{ml}$. Irradiated $\mathrm{T}$ cells have been shown by a number of investigators to function as efficient helper cells $(11,12)$. Unlike unirradiated $T$ cells, which tend to suppress $B$ cell responses at high $T: B$ ratios, irradiated $T$ cells function as helpers over a broad range of $\mathrm{T}: \mathrm{B}$ ratios. Addition of $\mathrm{Tx}$ to $\mathrm{PBM}$ in a $1: 1$ ratio was consistent in enhancing plaque-forming cell (PFC) responses of normal PBM, and because of limitations in cells obtained from patients, this ratio was routinely used for patient studies.

Co-culture experiments were performed by mixing equal proportions of test cells (i.e., of patient and of normal controls) keeping the final cell concentrations and volume constant at $1 \times 10^{6} \mathrm{cells} / \mathrm{ml}$. The observed response was expressed as a percentage of the expected response, the latter representing a mean of the responses of the two individuals cultured separately.

Study of T lymphocyte differentiation. Induction of T cell markers on fractionated bone marrow cells by thymic epithelial monolayers (TEM) was tested as previously described (5). Briefly, marrow from the patients was fractionated first on sodium metrizoate/Ficoll cushions and further separated either into five layers on discontinuous density gradients of Ficoll or into three pools by velocity sedimentation. Fractionated marrow cells from each layer or pool were cocultured at a concentration of $3 \times 10^{6}$ cells $/ \mathrm{ml}$ with TEM, and with medium as control for $15 \mathrm{~h}$ at $37^{\circ} \mathrm{C}$ in $5 \% \mathrm{CO}_{2}$, and subsequently tested for presence of human $\mathrm{T}$ lymphocyte antigen (HTLA), for rosette formation with sheep erythrocytes (E rosettes) (13), and for responsiveness to the mitogens phytohemagglutinin, concanavalin A, and PWM (14). Determination of HTLA was performed in a microcytotoxicity assay (15) with a specific antihuman $T$ cell serum (Institut Merieux, Lyon, France).

\section{RESULTS}

PFC responses in normal volunteers. PBM of volunteers routinely used as controls varied widely in their PFC responses to stimulation with PWM. During the entire period of the studies reported here, 95 volunteers ranging in age from $20-45 \mathrm{yr}$ were tested with a mean response of $181 \pm 161$ (mean $\pm 1 \mathrm{SD}$ ), and a range of 24-669 PFC/106 cells. In this group of volunteers, there were good responders and poor responders. The pattern of responses, however, remained consistent, in that good responders responded well and the poor responders manifested low responses on repeated interval analyses. These observations are consistent with those made by others using this culture system $(10,16)$.

Age-matched controls were not tested simultaneously with the patients. Humoral immune responses in vitro have been shown by several investigators to be deficient at birth, and anti-sheep erythrocyte PFC responses have not been evaluated at an early age. However, studies conducted in this laboratory in a few children less than 2 yr old who were tested to rule out immunodeficiency disease have shown that they are able to respond in this assay system (unpublished observations).

In PBM cultures without added PWM, and in cultures of irradiated T cells with or without PWM, responses were usually zero and always $<7 \mathrm{PFC} / 10^{6}$ cells. In allogeneic co-culture experiments, observed responses between pairs of responder individuals did not deviate significantly from the expected (mean \pm 1 SD of 1 percent observed/expected responses in normal allogeneic PBM cocultures was equal to $91 \pm 35 \%$ ).

PFC responses in PBM of patients with SCID. When PBM from patients were cultured by themselves in the presence of PWM, no PFC were generated (Table I). Addition of irradiated allogeneic $\mathrm{T}$ cells to patient PBM cultures elicited PFC responses of varying mag- 
TABLE I

PFC Responses in PBM of Patients with SCID

\begin{tabular}{|c|c|c|c|c|c|}
\hline \multirow[b]{2}{*}{ Patients* } & \multirow[b]{2}{*}{ ADA } & \multicolumn{2}{|c|}{ Lymphocytes } & \multirow[b]{2}{*}{ PBM } & \multirow[b]{2}{*}{$\mathbf{P B M}+\mathbf{T} \mathbf{x}^{\mathbf{d}}$} \\
\hline & & Bt & $T \S$ & & \\
\hline & & \multicolumn{2}{|c|}{$\%$} & \multicolumn{2}{|c|}{ plaques $10^{6}$ cells } \\
\hline $\mathbf{A}$ & + & 18 & 3 & 0 & 0 \\
\hline B & + & 84.5 & 2 & 0 & 141 \\
\hline C & - & 7 & 1 & $\mathbf{0}$ & 0 \\
\hline $\mathbf{F}$ & + & 22.5 & 9.5 & 0 & 24 \\
\hline $\mathrm{G}$ & + & 0 & 9.5 & 0 & 0 \\
\hline $\mathbf{H}$ & + & 97.5 & 3.5 & 0 & 22 \\
\hline I & - & 12 & 3 & 0 & 0 \\
\hline $\mathbf{J}$ & + & 72 & 30 & 2 & 167 \\
\hline $\mathbf{K}$ & + & 14 & 71 & 0 & 9 \\
\hline Normal controls & & & & & \\
\hline mean $\pm 1 \mathrm{SD}$ & + & $17 \pm 7$ & $72 \pm 12$ & $181 \pm 161$ & $\|$ \\
\hline
\end{tabular}

* Symbols identifying patients same as those used in previous publication (5). Patients B and F studied after fetal liver transplantation at a time when chimerism was demonstrable without immune reconstitution.

† Surface Ig-positive lymphocytes stained with fluorescein conjugated polyvalent rabbit anti-human Ig antiserum.

$\S$ Lymphocytes forming spontaneous rosettes with sheep erythrocytes. T cells of patient $\mathrm{K}$ were of maternal origin, as determined by sex karyotype.

" Normal irradiated T cell (1,500 rad) added to PBM cultures in a 1:1 ratio. Response of 14 normal volunteers with added T lymphocytes was $284 \pm 116 \%$ (mean $\pm 1 \mathrm{SD}$ ) of that obtained when cultured alone.

nitudes in five patients $(\mathrm{B}, \mathrm{F}, \mathrm{H}, \mathrm{J}$, and $\mathrm{K})$. Two of these patients ( $B$ and $F$ ) had been given fetal liver transplantation and demonstrated chimerism with fetal derived lymphocytes in their peripheral blood. Thus, it is not clear whether the responses elicited in these two patients were from host- or donor-derived B cells. In the other three patients who responded, circulating $B$ cells were markedly elevated in two ( $\mathrm{H}$ and $\mathrm{J}$ ) and normal in the third. A complete absence of circulating $B$ cells was noted in only one of the four nonresponders. Normal levels of B cells were present in one nonresponder, and slightly decreased levels in the other two. These observations suggest that the deficiency of peripheral blood B cell function may be at least partially reversed in vitro (by provision of allogeneic helper cells) in some cases of SCID associated with presence of circulating B cells.

Tests for suppressor cells in patients with SCID. To see if failure of $B$ cell responsiveness could be attributed to excessive suppressor cells, patient PBM were co-cultured with normal PBM and PFC responses of the cell mixtures were quantitated. Co-culture of PBM obtained from previously untreated patients with normal PBM quite often resulted in enhancement of expected responses (Fig. 1). Suppression was occasionally noted in cocultures containing cells from patients

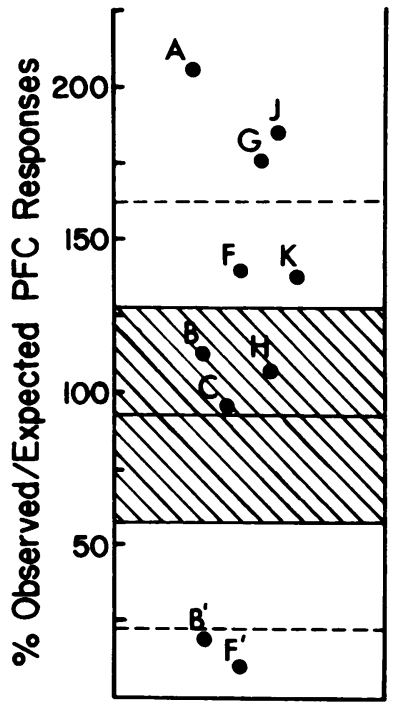

FIGURE 1 Results of co-culturing patient PBM with normal PBM calculated as a percentage of expected responses (see text). Individual patient results designated by appropriate symbols. $B^{\prime}$ and $F^{\prime}$ indicate results obtained when patients $B$ and $F$ were tested during a period when their PBM failed to respond to PWM even in presence of allogeneic helper cells. Results of coculturing pairs of unrelated normal PBM shown in figure by shaded area (67\% confidence limits) and by broken lines ( $95 \%$ confidence limits). 
who had been given fetal liver transplantation, for example, patients $B$ and F. Points $B^{\prime}$ and $F^{\prime}$ in Fig. 1 represent results of allogeneic co-cultures containing PBM of patients $B$ and $F$ at a time when PBM of these patients were incapable of responding to PWM, even with added helper cells. At other times, however, when PFC responses could be elicited in the presence of added helper cells, no suppression was seen in allogeneic co-cultures of patient and normal PBM (points $\mathrm{B}$ and $\mathrm{F}$ in Fig. 1).

Suppressor cells for matched sibling in patient $H$. Patient $\mathbf{H}$ had high proportions of circulating B lymphocytes, and yet his PBM had poor PFC responses even in presence of $T x$ cells. Co-culture of patient $P B M$ with allogeneic PBM did not lead to suppression of expected responses. The possibility that suppressor cells with genetic restrictions might be present in this patient was investigated by co-culturing his cells with those of his histocompatible sibling who was matched with $\mathrm{H}$ at the HLA-A, -B, and -D loci. As shown in Table II, marked suppression was seen in lymphocyte co-cultures of $\mathrm{H}$ with sibling, but not in those of $\mathrm{H}$ with PBM from an unrelated control, or of his sibling's PBM with unrelated control PBM. These observations were suggestive of a specific suppressor cell with genetic restriction in patient $\mathrm{H}$. The suppression observed was abolished when the patient's cells were irradiated (1,500 rad).

PFC responses in bone marrow of patient $H$. To test further the possibility that $B$ cells of this patient were capable of function, PFC responses were tested in his bone marrow lymphocytes. The latter could be obtained in amounts adequate to allow cell fractionation so as to selectively enrich for B cell precursors.

Marrow cells, fractionated by sedimentation velocity, were cultured with PWM in the presence and absence of Tx lymphocytes. As shown in Table III, a vigorous PFC response was elicited in pool $2 b$ of the bone marrow (consisting of medium sized lymphocytes) in the presence of Tx lymphocytes. Marrow cells of two other

TABLE II

Suppressor Cells in Peripheral Blood of Patient $\mathrm{H}$

\begin{tabular}{lc}
\hline Source of cells & Plaques $/ 10^{6}$ cells \\
\hline Patient $(\mathrm{Pt})$ & 0 \\
Sibling (S) & 277 \\
Unrelated (U) & 350 \\
& \\
$\mathrm{Pt}+\mathrm{S}$ & $4(2)^{*}$ \\
$\mathrm{Pt}+\mathrm{U}$ & $150(108)$ \\
$\mathrm{S}+\mathrm{U}$ & $263(84)$ \\
$\mathrm{Pt}(\mathbf{x})+\mathrm{S}$ & 145 \\
$\mathrm{Pt}(\mathbf{x})+\mathrm{U}$ & 226
\end{tabular}

* Results in parentheses represent \% of expected response.

f Pt cells irradiated to $1,500 \mathrm{rad}$.
TABLE III

PFC Responses in Bone Marrow of Patient $H$

\begin{tabular}{lccr}
\hline $\begin{array}{c}\text { Bone marrow } \\
\text { pool* }\end{array}$ & $\begin{array}{c}\text { Sedimentation } \\
\text { velocity }\end{array}$ & Bone marrow & $\begin{array}{r}\text { Bone marrow } \\
+\mathrm{Tx}\end{array}$ \\
\hline & $m m / h$ & \multicolumn{2}{c}{ plaques $/ 0^{6}$ cells } \\
$2 \mathrm{a}$ & $4.9-5.6$ & 1 & 0 \\
$2 \mathrm{~b}$ & $3.9-4.7$ & 0 & 907 \\
3 & $1.5-3.5$ & 0 & 6 \\
\hline
\end{tabular}

* Bone marrow was fractionated by sedimentation at unit gravity and then pooled as described in the text.

patients ( $K$ and $G$ ) were tested in a similar manner (data not shown), but failed to respond even with added helper cells $(\mathrm{Tx})$ in the cultures. These results indicate that $\mathrm{B}$ cells of patient $\mathrm{H}$ were indeed functional but that their responses were inhibited in their usual environment.

PFC responses in the bone marrow of an ADA-deficient patient (patient I). In patient I whose PBM also failed to respond in vitro, PFC responses of fractionated bone marrow lymphocytes were tested in a manner similar to that employed for the patients described above. No PFC were generated upon stimulation of the lymphoid fractions of bone marrow with PWM. Attempts were made to reconstitute the response with the addition of exogenous ADA and/or allogeneic irradiated T cells. As shown in Table IV, the patients' cells did not respond either with the addition of ADA, $20 \mathrm{U} / \mathrm{ml}$, or of allogeneic Tx cells to the cultures. However, a good PFC response was noted when both ADA and $\mathrm{Tx}$ lymphocytes were added to cultures of patient's cells.

T lymphocyte differentiation in patients with SCID. Studies of T lymphocyte differentiation in fractionated marrow cells of the patients herein have been described in detail (5). It has been proposed that in the normal sequence of $\mathrm{T}$ lymphocyte differentiation acquisition of human $\mathrm{T}$ lymphocyte antigenicity precedes the ability to form rosettes with sheep erythrocytes. The latter step is followed by functional competence as tested by proliferation in response to mitogens. Co-culture of

TABLE IV

PFC Responses in Bone Marrow of an ADA-deficient SCID Patient (I)

\begin{tabular}{lcr}
\hline $\begin{array}{c}\text { Bone marrow } \\
(\text { pools } 2 \mathrm{~b}+3)\end{array}$ & Bone marrow & $\begin{array}{c}\text { Bone marrow } \\
+\mathrm{Tx}\end{array}$ \\
\hline & \multicolumn{3}{c}{${\text { plaques } / 10^{6} \text { cells }}$} \\
Cultured alone & 0 & 0 \\
With exogenous ADA* $^{*}$ & 0 & 106 \\
\hline
\end{tabular}

* ADA, $20 \mathrm{U} / \mathrm{ml}$ was added to patient cells at initiation of culture. 
normal fractionated marrow with thymic epithelial monolayers results in induction of all these characteristics in precursor cells. In Table $V$ are shown results of $\mathrm{T}$ lymphocyte differentiation in the marrow of patients $\mathrm{H}$ and $\mathrm{J}$, both of whom appeared to have functional B cells. Whereas induction of HTLA and E rosette-forming capacity was noted in the bone marrow of both of these patients, responsiveness to mitogens was induced only in patient J. Thus by this analysis $T$ lymphocyte differentiation in vitro was found to be blocked in patient $\mathrm{H}$ but not in patient $\mathrm{J}$. In the remaining patients, such studies revealed blocks at different stages in the proposed pathway of normal $\mathrm{T}$ cell differentiation; induction of responsiveness to mitogens was not observed in any patient other than patient J (5).

\section{DISCUSSION}

Heterogeneity of the SCID syndromes is becoming increasingly apparent $(5,17-20)$. In the patients reported here, B lymphocytes in the circulation varied from complete absence to markedly increased proportions. However, none of the patients generated PFC when their peripheral blood mononuclear cells were stimulated with PWM. The functional capability of the existing B cells in the PBM of these patients was further tested by providing exogenous help in the form of irradiated normal $T$ cells to cultures of patient PBM. Irradiated T cells have been shown to function efficiently as helper cells for B cell differentiation in PWM-driven systems $(11,12)$. With added help of this kind PFC responses of varying magnitudes were seen in PBM cultures of five patients. Two of these patients ( $B, F)$ had been given fetal liver transplantation before this study and demonstrated chimerism with donor-derived cells in their circulating lymphocytes as determined by sex karyo- type and/or HLA typing (6). It is unclear therefore whether the responding B cells were host- or donorderived. Of the remaining three patients, good PFC responses were noted in PBM of one patient $(\mathrm{J})$ and small responses in patients $\mathrm{H}$ and $\mathrm{K}$. The definite presence of functional $B$ cell precursors in patient $\mathrm{H}$ was substantiated by the observation that $\mathrm{PFC}$ responses could be elicited in fractionated marrow lymphocytes in the presence of exogenous helper $T$ cells. These observations extend those made previously which showed that some SCID patients have B cells in their circulating lymphocyte pool, capable of differentiating into the plasma cell stage (2) or into immunoglobulinsecreting cells (3) in the presence of normal $\mathrm{T}$ cells. Although a deficit in B cells per se would account for a lack of humoral immunity, only one nonresponder in our series lacked circulating B cells completely. Two patients ( $A$ and $K$ ) who had near normal levels of $B$ cells failed to respond even in presence of allogeneic helper cells. Thus, failure of B cell function in SCID patients can be explained only partially on the basis of a lack of $T$ cell help.

Differentiation of intrinsically normal B lymphocytes into antibody secreting cells can be hampered, not only by a lack of adequate numbers of helper cells, but also by an excess of suppressor cells. In the studies reported here, suppression was seldom noted in allogeneic co-cultures between patient and normal lymphocytes, and then only in situations where the patients had been given fetal tissue transplantations. Such suppression might have derived from cells that became activated by allogeneic interactions. In most instances, co-cultures between patient and normal allogeneic cells led to an enhancement of expected responses; similar observations were made by Buckley et al. (19) in another assay system. However, the likelihood that suppressor cells can play a role in the immunodeficiency of SCID be-

TABLE V

T Lymphocyte Differentiation in Bone Marrow of Patients $H$ and $J^{*}$

\begin{tabular}{lllcc}
\hline Patient & $\begin{array}{c}\text { Incubation } \\
\text { with }\end{array}$ & $\begin{array}{c}\text { HTLA } \\
\text { (cytotoxic } \\
\text { index) }\end{array}$ & $\begin{array}{c}\text { E rosettes } \\
(\%)\end{array}$ & $\begin{array}{c}\text { Concanavalin A } \\
\text { responses } 1\end{array}$ \\
\hline H & Medium & 18.5 & 19.7 & $173 \pm 42$ \\
& TEM & $35 \S$ & $32 \S$ & $238 \pm 34$ \\
J & Medium & 22 & 7 & $93 \pm 29$ \\
& TEM & $39 \S$ & $18.3 \S$ & $1,211 \pm 56 \S$ \\
$\begin{array}{l}\text { Normal bone } \\
\text { marrow }\end{array}$ & Medium & $27.5 \pm 5.1$ & $17.7 \pm 4.1$ & $4,000 \pm 1,200$ \\
\hline
\end{tabular}

* Marrow cells fractionated by velocity sedimentation, incubated for $15 \mathrm{~h}$ with medium or with TEM and tested for HTLA, E rosette-forming capacity, and proliferative response to concanavalin $\mathrm{A}$.

$\$\left[{ }^{14} \mathrm{C}\right]$ Thymidine uptake; peak response in a dose-response curve.

$\S$ Results showing significant induction (5). 
came apparent when patient H's cells were cocultured with those of his histocompatible sibling. In the latter co-cultures, a marked suppression of the expected PFC responses was observed. No suppression was noted in co-cultures of patient $\mathrm{H}$ cells with those of an unrelated person or in co-cultures between the same unrelated person and patient H's sibling's cells.

The immunodeficiency in patient $\mathbf{H}$ appears thus to have been associated with both a loss of helper cells as well as an excess of suppressor cells. By fractionation of bone marrow lymphocytes, B cell precursors were most likely freed of those cells which were mediating the suppression, thereby enabling them to respond in the presence of allogeneic helper $T$ cells. Similar fractionation procedures failed to yield PFC responses in two other patients so tested, one of whom (K) had near normal levels of circulating B cells. In the latter patient, failure of $B$ cells to respond can be attributed to intrinsic defects of $B$ cells. It is of interest that patient $\mathrm{H}$ who was treated by bone marrow transplantation from his matched sibling, manifested engraftment only of donor derived $T$ cells and retained his own B lymphocytes (6). Engraftment of donor B lymphocytes may have been suppressed in this situation, or possibly, the cytological niche for the establishment of this lineage was occupied by a vigorous competitive population of host B lymphocytes.

Suppression of humoral responses in patient $\mathrm{H}$ may have been mediated by a cell type requiring identity with some region of the histocompatibility complex. In the mouse, regulation of $T$ cell helper and suppressor activities appears to be associated with the I-region loci of the H-2 complex (21-24). In man, HLA-D region is believed to correspond to the I region of mice and genetically restricted suppressor cells requiring identity at the HLA-D region have been described (25). In our patient $H$ histocompatibility locus restrictions, if any, for suppressor cell function are not known. With regard to the nature of the suppressor cells, their radiosensitivity makes monocytes unlikely candidates. $\mathrm{T}$ lymphocytes although scarce in the peripheral blood (but more abundant in fractionated marrow) might have been sufficient to exert the suppression observed. The remote possibility that B lymphocytes themselves were the effectors of suppression must also be considered.

Not only did the patients studied here manifest heterogeneity in their B cell responses, a marked heterogeneity was noted in the differentiation responses of their bone marrow $T$ cell precursors (5). Of the two patients in whom definite presence of functional B cells was documented in vitro, $T$ cell differentiation was blocked in one $(\mathrm{H})$ but not in the other $(\mathrm{J})$. It would appear that patients like $\mathrm{J}$ who have normal $\mathrm{T}$ as well as $B$ cell precursors comprise a small population of SCID patients in whom the basic defect might be restricted in the thymus as proposed by Hong et al. $(26,27)$ and Gelfand et al. $(4,28)$, and such patients might be immunologically reconstituted by treatment with thymus transplantation alone. The majority of the patients, however, have stem cell defects involving the $T$ cell lineage with or without involvement of B cell lineage. In the latter group, engraftment with normal precursors of $T$ cells might be sufficient to allow function of existing host B lymphocytes.

Some patients with SCID have an associated deficiency of the adenosine deaminase enzyme in their lymphocytes and erythrocytes (29). The exact basis of immunodeficiency in ADA-negative SCID patients is as yet unclear. It has been suggested that absence of ADA results in accumulation of toxic metabolites which impair lymphocyte differentiation (30-32). Addition of ADA to lymphocyte cultures in vitro (33) and enzyme replacement in vivo (20) have reconstituted immune responses in some but not all patients with this form of SCID. In the patient reported here, both ADA and $T x$ were needed to reconstitute $B$ cell function in vitro. In vivo, the patient failed to respond to enzyme replacement (with erythrocyte transfusions) alone. Treatment with fetal thymus transplantation coupled with enzyme replacement therapy, however, appears to have reconstituted this patient at least partially for both $B$ and $T$ cell functions. Again, it is apparent that SCID with ADA deficiency comprises yet another heterogeneous group.

Reconstitution of B cell function is often difficult in some patients with SCID; treatment with bone marrow or fetal tissue transplantation may result only in $T$ cell reconstitution and these patients either continue to lack B cells or the B cells of host origin persist but do not attain normal function (34-37). Insight into problems relating to $B$ cell engraftment may be attained by a clearer understanding of $B$ lymphocyte differentiation, helper function, and suppressor influences operating in this disease. Investigation into putative genetically restricted suppressor cells, and identification of the locus determining such restriction are very much in order.

\section{ACKNOWLEDGMENTS}

We are indebted to Doctors Richard J. O'Reilly, Neena Kapoor, and Michael Sorell of the Marrow Transplant Unit and Dr. F. Papagiorgio for their cooperation in providing blood and bone marrow samples on patients; to Dr. Elizabeth Smithwick for helpful advice; to Dr. R. Hirschhorn for supplying ADA; and to Mss. A. Manice, C. Tsao, and E. Espiritu for technical assistance.

This project was supported by grants from the National Institutes of Health CA-08748, CA-19267, CA-17404, AI-11843, and NS-11457; the Judith Harris Selig Memorial Fund; the Zelda R. Weintraub Cancer Fund; and the Charles E. Merrill Trust. 


\section{REFERENCES}

1. Fudenberg, H. H., R. A. Good, H. C. Goodman, W. Hitzig, H. G. Kunkel, I. M. Roitt, F. S. Rosen, D. S. Rowe, M. Seligmann, and J. R. Soothill. 1971. Primary immunodeficiencies. Bull. W. H. O. 45: 125-142.

2. Griscelli, C., A. Durandy, J. L. Virelizier, J. J. Ballet, and F. Daguillard. 1978. Selective defect of precursor T cells associated with apparently normal B lymphocytes in severe combined immunodeficiency disease.J. Pediatr. 93: 404-411.

3. Seeger, R. C., R. A. Robins, R. H. Stevens, R. B. Klein, D. J. Waldman, P. M. Zeltzer, and S. W. Kessler. 1976. Severe combined immunodeficiency with B lymphocytes: in vitro correction of defective immunoglobulin production by addition of normal T lymphocytes. Clin. Exp. Immunol. 26: 1-10.

4. Pyke, K. W., H. M. Dosch, M. M. Ipp, and E. W. Gelfand. 1975. Demonstration of an intrathymic defect in a case of severe combined immunodeficiency disease. N. Engl. J. Med. 293: 424-428.

5. Pahwa, R. N., S. G. Pahwa, and R. A. Good. 1979. T-lymphocyte differentiation in severe combined immunodeficiency. Defects of stem cells. J. Clin. Invest. 64: $1632-1641$.

6. O'Reilly, R., R. Pahwa, M. Sorell, N. Kapoor, A. Kapadia, D. Kirkpatrick, M. Pollack, B. Dupont, G. Incefy, T. Iwata, and R. A. Good. 1979. Transplantation of fetal liver and thymus in patients with severe combined immunodeficiencies. In The Immune System: Functions and Therapy of Dysfunction. International Symposium, Stresa, Italy, 1978. Academic Press, Inc., New York. In press.

7. Miller, R. G., and R. A. Phillips. 1969. Separation of cells by velocity sedimentation. J. Cell. Physiol. 73: 191-201.

8. Weiner, M. S., C. Bianco, and V. Nussenzweig. 1973. Enhanced binding of neuraminidase treated sheep erythrocytes to human T lymphocytes. Blood. 42: 939-946.

9. Pahwa, S., L. Shou, R. Pahwa, E. Smithwick, and R. A. Good. 1979. Influence of human thymocytes on B-cell differentiation. Cell. Immunol. 44: 434-441.

10. Fauci, A. S., and K. R. Pratt. 1976. Polyclonal activation of bone marrow derived lymphocytes from human peripheral blood measured by a direct plaque-forming cell assay. Proc. Natl. Acad. Sci. U. S. A. 73: 3676-3679.

11. Siegal, F. P., and M. Siegal. 1977. Enhancement by irradiated $\mathrm{T}$ cells of human plasma cell production: dissection of helper and suppressor function in vitro. J. Immunol. 118: 642-647.

12. Fauci, A. S., K. R. Pratt, and G. Whalen. 1978. Activation of human B lymphocytes. VIII. Differential radiosensitivity of subpopulations of lymphoid cells involved in the polyclonal-induced PFC responses of peripheral blood B lymphocytes. Immunology. 35: 715-720.

13. Bentwich, Z., S. D. Douglas, F. P. Siegal, and H. G. Kunkel. 1973. Human lymphocyte-sheep erythrocyte rosette formation: some characteristics of the interaction. Clin. Immunol. Immunopathol. 1: 511-522.

14. Cunningham-Rundles, S., J. A. Hansen, and B. Dupont. 1976. Lymphocyte transformation in vitro in response to mitogens and antigens. In Clinical Immunobiology. F. H. Bach and R. A. Good, editors. Academic Press, Inc., New York. 3: 151-194.

15. Touraine, J. L., G. S. Incefy, F. Touraine, Y. M. Rho, and R. A. Good. 1974. Differentiation of human bone marrow cells into $\mathrm{T}$ lymphocytes by in vitro incubation with thymic extracts. Clin. Exp. Immunol. 17: 151-158.

16. Fauci, A. S. 1979. Human B cell function in a polyclonal induced plaque forming cell system. Cell triggering and immunoregulation. Immunol. Rev. 45: 93-116.

17. Incefy, G. S., E. Grimes, W. A. Kagen, G. Goldstein, E. Smithwick, R. J. O'Reilly, and R. A. Good. 1976. Heterogeneity of stem cells in severe combined immunodeficiency. Clin. Exp. Immunol. 25: 462-471.

18. Pahwa, R., S. Pahwa, R. O'Reilly, and R. A. Good. 1978. Treatment of the immunodeficiency diseases-progress towards replacement therapy emphasizing cellular and macromolecular engineering. Springer Semin. Immunopathol. 1: 355-404.

19. Buckley, R. H., R. B. Gilbertsen, R. I. Schiff, E. Ferreira, S. O. Sanal, and T. A. Waldmann. 1976. Heterogeneity of lymphocyte subpopulations in severe combined immunodeficiency. J. Clin. Invest. 58: 130-136.

20. Polmar, S. H., R. C. Stern, A. L. Schwartz, E. M. Wetzler, P. A. Chase, and R. Hirschhorn. 1976. Enzyme replacement therapy for adenosine deaminase deficiency and severe combined immunodeficiency. N. Engl.J. Med. 295: 1337-1343.

21. Tada, T., M. Taniguchi, and C. S. David. 1976. Properties of the antigen-specific suppressive $\mathrm{T}$-cell factor in the regulation of antibody responses of the mouse. IV. Special subregion assignment of the gene(s) that codes for the suppressive $\mathrm{T}$-cell factor in the $\mathrm{H}-2$ histocompatibility complex. J. Exp. Med. 144: 713-725.

22. Tada, T., M. Taniguchi, and K. Okumura. 1977. Regulation of antibody response by antigen specific $\mathrm{T}$-cell factors bearing I-region determinants. Prog. Immunol. 3: 369377.

23. Taussig, M. J., and A. J. Munro. 1976. Antigenspecific Tcell factor in cell cooperation and genetic control of the immune response. Fed. Proc. 35: 2061-2066.

24. Benacerraf, B., and R. N. Germain. 1978. The immune response genes of the major histocompatibility complex. Immunol. Rev. 38: 70-119.

25. Engleman, E. G., and H. O. McDevitt. 1978. A suppressor $T$ cell of the mixed lymphocyte reaction specific for the HLA-D region in man. J. Clin. Invest. 61: 828-838.

26. Hong, R., M. Santosham, H. Schulte-Wissermann, S. Horowitz, S. H. Hsu, and J. A. Winkelstein. 1976. Reconstitution of $\mathrm{B}$ and $\mathrm{T}$ lymphocytes function in severe combined immunodeficiency disease after transplantation with thymic epithelium. Lancet. II: 1270-1272.

27. Hong, R., H. Schulte-Wissermann, S. Horowitz, M. Borzy, and J. Finlay. 1978. Cultured thymic epithelium in severe combined immunodeficiency. Transplant Proc. 10: 201202.

28. Gelfand, E. W., H. M. Dosch, J. Huber, and A. Shore. 1977. In vitro and in vivo reconstitution of severe combined immunodeficiency disease with thymic epithelium. Clin. Res. 25: 358A. (Abstr.)

29. Giblett, E. R., J. E. Anderson, F. Cohen, B. Pollara, and H. J. Meuwissen. 1972. Adenosine-deaminase deficiency in two patients with severely impaired cellular immunity. Lancet. II: 1067-1069.

30. Mills, G. C., F. C. Schmalstieg, K. B. Trimmer, A. S. Goldman, and R. M. Goldblum. 1976. Purine metabolism in adenosine deaminase deficiency. Proc. Natl. Acad. Sci. U. S. A. 73: 2867-2871.

31. Schmalstieg, F. C., J. A. Nelson, G. C. Mills, T. M. Monahan, A. S. Goldman, and R. M. Goldblum. 1977. Increased purine nucleotides in adenosine deaminasedeficient lymphocytes. J. Pediatr. 91: 48-51.

32. Cohen, A., R. Hirschhorn, S. D. Horowitz, A. Rubenstein, S. H. Polmar, R. Hong, and D. W. Martin. 1978. 
Deoxyadenosine triphosphate as a potentially toxic metabolite in adenosine deaminase deficiency. Proc. Natl. Acad. Sci. U. S. A. 75: 472- 476.

33. Polmar, S. H., E. M. Wetzler, R. C. Stern, and R. Hirschhorn. 1975. Restoration of in vitro lymphocyte responses with exogenous adenosine-deaminase in a patient with severe combined immunodeficiency. Lancet. II: 743-746.

34. Geha, R. S. 1976. Is the B cell abnormality secondary to $T$ cell abnormality in severe combined immunodeficiency? Clin. Immunol. Immunopathol. 6: 102-106.

35. Vossen, J. M., J. DeKoning, D. W. van Bekkum, K. A. Dicke, P. P. Eijsvoogel, H. Hijams, E. Van Logem, J. Radl,
J. J. Van Rood, D. Van Der Waay, and L. J. Dooren. 1973. Successful treatment of an infant with severe combined immunodeficiency by transplantation of bone marrow cells from an uncle. Clin. Exp. Immunol. 13: 9-20.

36. Buckley, R. H., J. K. Whisnant, R. I. Schiff, R. B. Gilbertsen, A. T. Huang, and M. S. Platt. 1976. Correction of severe combined immunodeficiency by fetal liver cells. N. Engl. J. Med. 294: 1076-1081.

37. Rieger, C. H. L., J. V. Lustig, R. Hirschhorn, and R. Rothberg. 1977. Reconstitution of T cell function in severe combined immunodeficiency disease following transplantation of early embryonic liver cells. J. Pediatr. 90: 707-712. 